\title{
Effect of Deficit Irrigation on Vegetative Growth and Yield of Potato Crop under the Semi Arid Condition of Tunisia
}

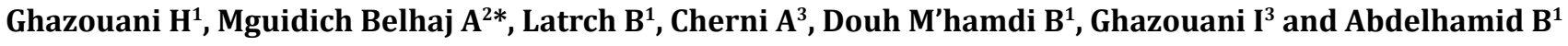 \\ ${ }^{1}$ Department of Rural Engineering, Higher Institute of Agronomy, Chott_Mariem Sousse (ISA-CM), Université de Sousse, Tunisia \\ ${ }^{2}$ Olive Institute Sousse, Tunisia \\ ${ }^{3}$ Higher School of Agriculture of Kef, Kef, University of Jendouba, Tunisia \\ *Corresponding Author: Mguidich Belhaj A, Olive Institute Sousse, Tunisia.
}

Received: June 24, 2019; Published: July 19, 2019

DOI: $10.31080 /$ ASAG.2019.03.0580

\begin{abstract}
In that study, the effect of deficit irrigation on vegetative growth and potato yield was investigated. Experiments were carried out at the High Agronomic Institute of Chott Meriem, Sousse, in an experimental plot, $25 \mathrm{~m}$ length and $7 \mathrm{~m}$ wide. The experimental plot was divided in two subplots (treatments T1, T2) subjected to similar seasonal management, except for irrigation doses. T1 received the exact level of maximum evapotranspiration while T2 received half the dose provided on T1. Results showed that canopy cover resulted statistically not significant between T1 and T2 for the first period of the growth cycle. After that, differences became significant $(\mathrm{P}<0.05)$, with lower values in $\mathrm{T} 2$ compared to $\mathrm{T} 1$. Regarding yield production, similarly to canopy cover, yield productions resulted significantly not different for the first period of growth cycle. However, during the period of full development stage differences were significant, as a result of higher irrigation volumes, provided in treatment T1 compared to T2. Irrigation water use efficiency resulted significantly higher in treatment receiving less irrigation depth. Moreover, irrigation water use efficiency was higher in the 2014 as a result of lower evapotranspiration demand and higher cumulative precipitation depth, in 2014 compared to 2015.
\end{abstract}

Keywords: Deficit Irrigation; Irrigation Water Use Efficiency (IWUE)

\section{Introduction}

Under Mediterranean condition, water stress is the most limiting ecological factor for food quality and crop production [1]. Crop responses to water deficit is a result of a local characterization in soil plant atmosphere system. Since phases of plant growth, make a diverse water stress effect [3]. Projections in the near future expects a great competition to reallocate water for agricultural, industrial and urban needs. However, irrigated agriculture is consuming more and more amounts of water, with percentages up to $70-80 \%$ of the total resources in arid and semi-arid regions [4], where irrigation is a key factor to intensify agricultural productivity and to fulfil sustainable agricultural development. In Tunisia, irrigated area in the country rose from 65,000 ha in 1956 to 408,000 ha in 2010 and, with a percentage of $8 \%$ of the potential cultivable lands, provide about $35 \%$ of total agricultural production [5]. The national water policies are oriented to increase irrigated areas and to mobilize surface and groundwater resources, even when they are characterized by low quality [4]. Moreover, due to the chronic scarcity of good water quality in fact, Tunisian farmers are quite often enhanced to use marginal waters, such as wastewaters from urban areas or saline waters, whose application could cause salt accumulation in the root zone with inhibition of root water uptake and reductions of crop yield [4]. Horticultural crops are the most water demanding crops compared to arboreal or cereal. In the country, potato crop with more than 50 varieties, represents the second main crop, with a total surface of 27,000 ha $(7 \%$ of irrigated lands) and a total production of 360,000 tons per year [6]. In order to increase irrigation water use efficiency, it is recommended to adopt an appropriate and well-designed irrigation system from one hand, and to identify irrigation strategies for optimizing crop water use.

Compared to other irrigation methods, subsurface drip irrigation systems (SDI) are considered the most efficient since they allow "application of water below the soil surface through emitters, with discharge rates generally in the same range of the drip irrigation". 
However, the most effective way to increase WUE is the precise control of irrigation. Several strategies aimed to reduce irrigation volumes have been developed, such as regulated deficit irrigation (RDI) and partial root absorption (PRD), which are often controlled by actual water status on the soil/plant-atmosphere continuum (vegetation water potential, sap flow meters, infrared thermography, etc.). Under RDI method, water is provided at levels lower than crop transpiration demand during the growing season. A number of previous studies demonstrated that RDI allows optimizing the number of fruits, fruit size and quality, and keeping plant vigor in balance with potential production [7]. For other crops, Root zone exposed to water deficit induces a root-toshoot signaling mechanism, such as abscisic acid (ABA) synthesis leading to a total or partial stomatal closure maintaining a good plant water status due to the watered root side [8]. Being word wide extensively documented for potato crop [9], Deficit irrigation has not been experimented yet under the semi-arid conditions of Tunisia, so that there is no information available. However, all the previous researchers consider deficit irrigation difficult to manage due to the rapid effect of water stress on tuber yield [10]. The main objective of these study is to evaluate the effect of deficit irrigation on potato crop growth; In particular, the effect of water stress on canopy cover development, yield productions and final irrigation water use efficiency will be investigated.

\section{Materials and Methods}

Experiments were carried out at the High Agronomic Institute of Chott Meriem, Sousse, Tunisia (longitude $10.5632^{\circ} \mathrm{W}$; latitude $35.9191^{\circ} \mathrm{N}$, altitude $19.0 \mathrm{~m}$ a.s.l.). The study area is characterized by semi-arid climate. The summer is hot and dry and the winter is mild-rainy. In 2014 and 2015, tuber seeds of the potatoes cultivar (Solanum Tuberosum L., cv. Safran), were planted on January, 15th and on January, 22nd, respectively, at distance of $0.40 \mathrm{~m}$ along the row and $0.80 \mathrm{~m}$ between the rows, in an experimental plot, 25 $\mathrm{m}$ length and $7 \mathrm{~m}$ wide. The experimental plot was divided in two subplots (treatments $\mathrm{T} 1, \mathrm{~T} 2$ ) subjected to similar seasonal management, except for irrigation doses. T1 received the exact level of maximum evapotranspiration while $\mathrm{T} 2$ received half the dose provided on T1. During experiments investigation, a climate station allowed acquiring daily values of maximum and minimum temperature, relative humidity, wind speed and solar radiation, necessary for the computation of reference evapotranspiration according to the Penman Monteith equation. Volumetric Soil water content were monitored using a Trime TDR, characterized by a precision of \pm 0.03 $\mathrm{cm}^{3} / \mathrm{cm}^{3}[5]$.

In order to monitor the dynamic of root length and leaf area during the seasonal growth cycle, in 2014 and 2015 three differ- ent plants were collected from random locations of each sub-plot, respectively at different dates from the planting date. In 2014, sampling was less intensive. In total 9 samples were analysed compared to 16 in 2015. For all samples, analyses aimed to measure the main root parameters in a first tile. Then, for these same plants, leaves were detached. The planimetric technique, implemented in the Skye Leaf v2 software (Skye Instruments Ltd.), was applied to measure the area of each plant leaf. The method is based on the proportionality between the individual leaf area and the number of area units covered by the same leaf placed in a horizontal plane [17]. The software was connected to a scanner permitting the capture of images that will be elaborated. After disposing leaves, the acquisition resolution was fixed by considering that higher resolutions need longer time analysis. Evaluation procedure started with large leaves individually, then small leaves were analysed jointly according to the scanner's surface dimensions. The last step allowed to select the scaling factor for image calibration and to fix a threshold function to train the software on which part of the image had to be analysed. Leaf area index were finally estimated by dividing the total leaf area by the surface occupied by a single plant. Finally, leaf area indexes were converted to CC using the following formula [18].

\section{$\mathrm{CC}=1.005[1-\exp (-0.6 \mathrm{LAI})]^{1.2}$}

In addition, starting from the date of tuber bulking stage, tubers were weighted using a precision balance in order to reproduce the temporal evolution of yield formation. In both years, three samples randomly chosen at nine days from the planting dates were analysed.

At the end of growth seasons, final yields were divided by the total volume provided by irrigation to compute values of irrigation water use efficiencies under the carried treatments.

\section{Results and Discussion}

Climate and soil characteristics of the study area

For treatments T1 and T2, Figure shows cumulated seasonal precipitation, irrigation, reference evapotranspiration ET0 for treatments $\mathrm{T} 1$ and $\mathrm{T} 2$, respectively in 2014 and 2015. As can be observed, 2014 presented lower value of cumulative value of reference evapotranspiration and higher precipitation height. Moreover, the number of raining days was more important during that year (40 in 2014 compared to 21 in 2015). These results leaded to more frequent and more important irrigation volumes in 2015.

Table 1 presents soil textural composition for the soil profile. For the three layers presents similar percentages of sand, silt and clay. Therefore, it was possible to characterize the soil with an average textural composition, as a sandy loamy soil. 


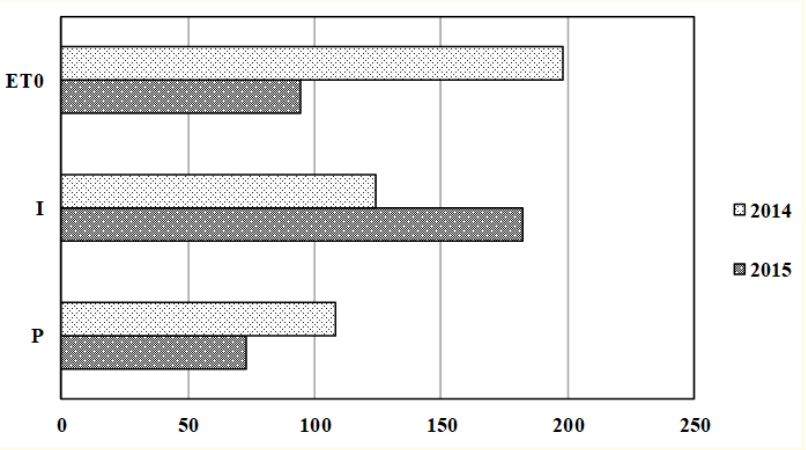

Figure 1: Cumulated seasonal precipitation, P, irrigation, I, reference evapotranspiration ET0 for treatments $\mathrm{T} 1, \mathrm{~T} 2$ in 2014 and 2015.

\begin{tabular}{|l|c|c|c|}
\hline Depth [cm] & CI [\%] & SI [\%] & Sa [\%] \\
\hline $0-20$ & 17.3 & 14.6 & 68.1 \\
\hline $20-40$ & 17.6 & 15.1 & 67.3 \\
\hline $40-60$ & 17.9 & 14.3 & 66.9 \\
\hline $0-60$ & 17.6 & 14.7 & 67.7 \\
\hline
\end{tabular}

Table 1: Textural composition of the soil for the three layers 0-20, 20-40 and 40-60.

\section{Effect of water stress on canopy cover development}

The values of canopy cover development, measured in 2014 and 2015 for treatments T1 and T2 are illustrated in figure $2 \mathrm{a}, \mathrm{b}$. Statistical differences in terms of canopy cover between T1 and T2 were not significant $(\mathrm{P}<0.05)$ during the first period of the growth. Therefore, despite the lower irrigation volume provided in treatment T2, crop did not lead to water stress conditions during the initial stage due to the precipitation events occurring during this period. On the contrary, during the full development stage, differences on canopy cover became significant $(\mathrm{P}<0.05)$, with lower values in $\mathrm{T} 2$ compared to $\mathrm{T} 1$ as result of the water stress to which the treatments were subjected.

The results are concordant with those presented by $[19,20]$, who demonstrated that among the morphological effects of water stress, cell division and enlargement (expansive growth) are most affected by water stress. They found that drought reduced significantly the final area of potato leaves And explained that leaf expansion is the first morphological parameter that reduces when soil water potential increases. At harvesting, significant differences between LAI measured in treatments T1 and T2 and in T3 and T4 can be also noticed, as consequence of the irreversible effects of water

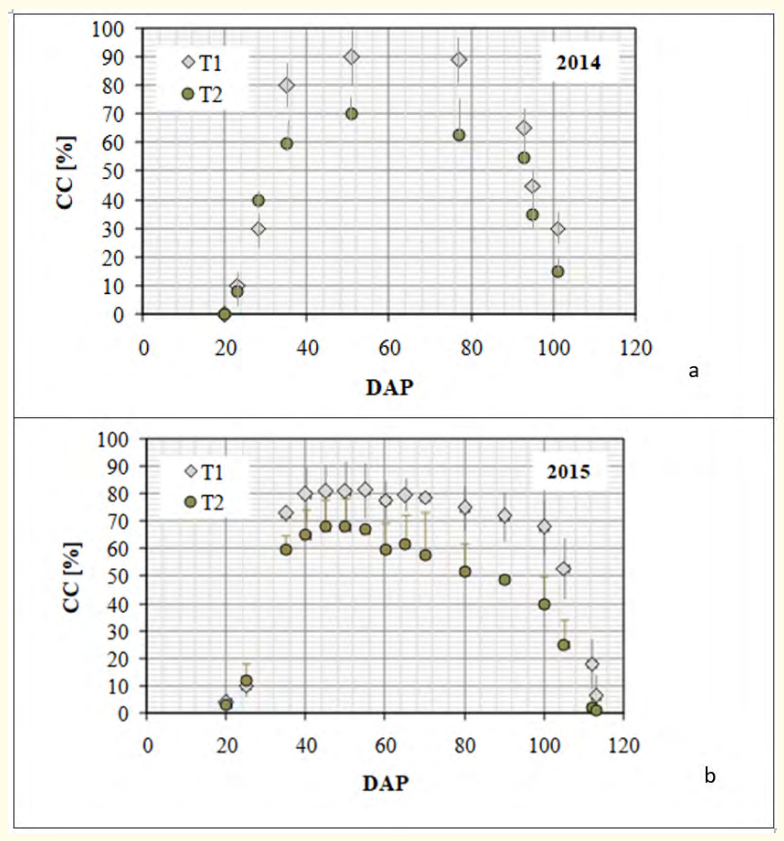

Figure 2: Effect of irrigation treatment on canopy cover development for 2014 (a) and 2015 (b).

stress on LAI. Even if water content at harvesting resulted around $20 \%$ in fact, differences in terms of LAI remained significant. They stated that the impact of stress on cell enlargement is irreversible, and the leaves enlargement rate do not return to the rate of unstressed plants even after copious irrigation

\section{Yield}

As it was observed for canopy cover development, yield productions for the first period of growth cycle resulted significantly not significant. However, during the period of full development stage differences became significant, as a result of higher irrigation volumes provided in treatmentT1 compared to T2. At the end of crop cycle, As can be observed, crop yield in treatment T1 in 2014 and 2015 resulted equal to 39.1 and 39.0 t/ha respectively; According to a Student's t-test $(\mathrm{P}<0.05)$, these differences resulted significant. Under Mediterranean climate, drought and heat stress are the main abiotic stresses occurring simultaneously during spring season and therefore the response of fresh tuber yield to applied water is greater during the winter compared to summer season. Based on experimental results obtained in Japan, Ka [15] observed reductions of tuber yield from $8.55 \mathrm{Kg} \mathrm{m}^{-2}$ to $4.89 \mathrm{Kg} \mathrm{m}^{-2}$ for conventional tuber and from $7.17 \mathrm{Kg} \mathrm{m}^{-2}$ to $4.01 \mathrm{Kg} \mathrm{m}^{-2}$ for micro-tubers, when delaying sowing time from May 13th to June 4 th and June $25^{\text {th }}$. 

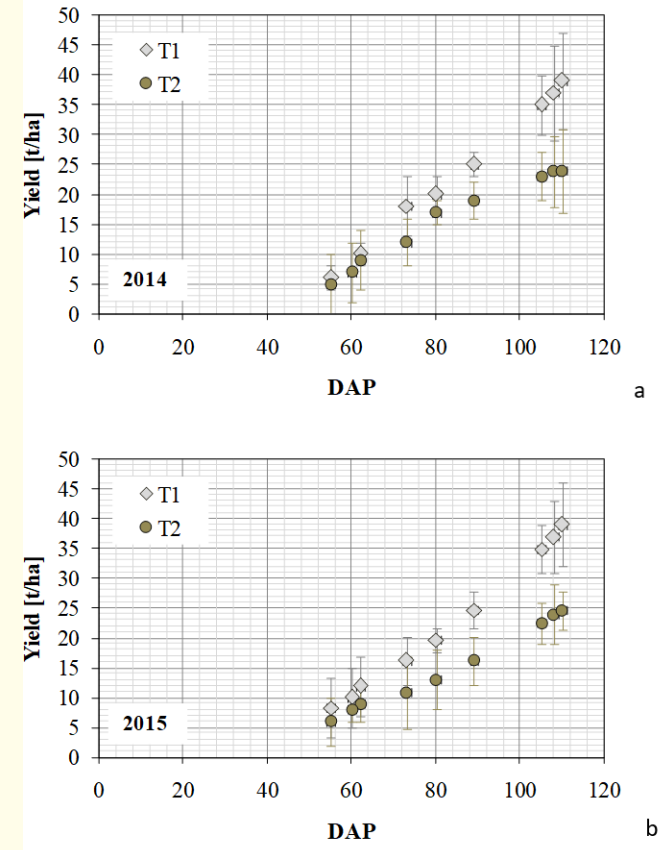

Figure 3: Effect of irrigation treatment on yield formation for 2014 (a) and 2015 (b).

IWUE

Figure shows the effect of the investigate treatment on irrigation water use efficiency for the investigated years of 2014 and 2015. As can be observed, irrigation water use efficiency resulted significantly higher in treatment receiving less irrigation depth. Moreover, IWUE was higher in the 2014. These results was mainly attributed to the lower evapotranspiration demand and the higher precipitation depth, observed in 2014 compared to 2015.

\section{Conclusion}

Experiments were carried out at the High Agronomic Institute of Chott Meriem, Sousse, Tunisia in order to evaluate the effect of deficit irrigation on potato crop growth and production (canopy cover development, yield productions evolution and final irrigation water use efficiency). In terms of canopy cover, Statistical differences between $\mathrm{T} 1$ and $\mathrm{T} 2$ were not significant $(\mathrm{P}<0.05)$ during the first period of the growth. However, differences on canopy cover became significant $(\mathrm{P}<0.05)$, with lower values in T2 compared to $\mathrm{T} 1$, during the full development stage. Like it was the case for canopy cover development, yield productions for the first period of growth cycle resulted significantly not different. However, during the period of full development stage differences were significant, as a result of higher irrigation volumes, provided in treat-
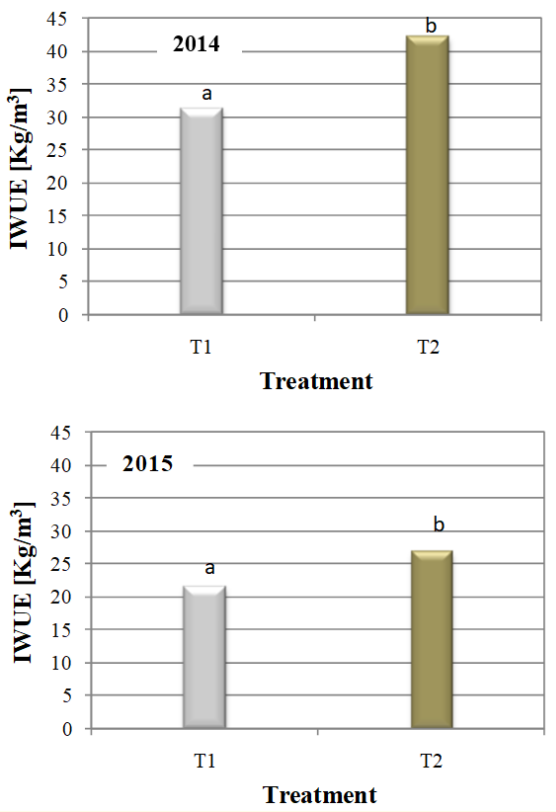

Figure 4: Effect of irrigation doses on irrigation on irrigation water use efficiency for 2014 (a) and 2015 (b).

ment T1 compared to T2. Irrigation water use efficiency resulted significantly higher in treatment receiving less irrigation depth. Moreover, IWUE was higher in the 2014 as a result of lower evapotranspiration demand and higher cumulative precipitation depth, in 2014 compared to 2015.

\section{Conflict of Interest}

Any financial interest and any conflict of interest exists.

\section{Bibliography}

1. Shao HB., et al. "Changes of some anti-oxidative physiological indices under soil water deficits among 10 wheat (Triticum aestivum L.) genotypes at tillering stage". Biointerfaces 54 (2007): 143-149.

2. Lishah $\mathrm{O}$ and Ahmadikhah A. "The Effects of Drought Stress on Improved Cotton Varieties in Golesatn Province of Iran". International Journal of Plant Production 3.1 (2009): 17-26.

3. Guendouz A., et al. "Genotypic and Phenotypic Correlations among Yield and Yield Components in Durum Wheat (Triticum durum Desf.) under Different Water Treatments in Eastern Algeria". Annual Research and Review in Biology 4.2 (2014): 432-442. 
4. Bouksila, F. "Sustainability of irrigated agriculture under salinity pressure - A study in semi arid Tunisia”. Doctoral Thesis, Lund University, Sweden. (2011).

5. Douh B. "Etude théorique et expérimentale de l'irrigation goutte à goutte souterraine sur une culture de maïs (Zea mays L.)". Thèse de doctorat en Science Agronomique, Higher Agronomic Institute of Chott Meriem (Sousse), (2012): 210.

6. Chehaibi S., et al. "Effects of planting depth on agronomic performance of two potato varieties grown in the Sahel region of Tunisia". Journal of Development and Agricultural Economics 5.7 (2013): 272-276.

7. Costa JM., et al. "Deficit irrigation as a strategy to save water: physiology and potential application to horticulture". Journal of Integrated Plant Biology 49 (2007): 1421-1434.

8. DE LA Hera ML., et al. "Is partial root-zone drying an effective irrigation technique to improve water use efficiency and fruit quality in field-grown wine grapes under semiarid conditions?". Agricultural Water Management 87 (2007): 261-274.

9. Foti S., et al. "Influence of irrigation levels on growth and yield of potato cv. Spunta”. Potato Research 38 (1995): 307-318.

10. FABEIRO C., et al. "Yield and size of deficit irrigated potatoes". Agricultural Water Management 48 (2001): 255-66.

11. Kayshap PS and PANDA RK. "Effect of irrigation scheduling on potato crop parameters under water stressed conditions". Agricultural Water Management 59 (2002): 49-66.

12. Yuan BZ., et al. "Effects of different irrigation regimes on the growth and yield of drip-irrigated potato". Agricultural Water Management 63 (2003): 153-167.

13. Onder S., et al. "Different irrigation methods and water stress effects on potato yield and yield components". Agricultural Water Management 73.1 (2005): 73-86.

14. Eldredge E.P., et al. "Effects of transitory water stress on potato tuber stem-end reducing sugar and fry color". American Potato Journal 73 (1996): 517-530.

15. Shock C.C., et al. "The effect of timed water stress on quality, total solids and reducing sugar content of potatoes". American Potato Journal 70.3 (1993): 227-241.
16. Wright JL., et al. In: B.A. Stewart and D.R. Nielsen, eds. Irrigation of Agricultural Crops - Agronomy. Monograph No. 30, Madison, Wisconsin, United States of America. (1990).

17. Jonckheere I., et al. "Review of methods for in situ leaf area index determination - Part I: Theories, sensors and hemispherical photography". Agricultural and Forest Meteorology 121.1-2 (2004): 19-35.

18. Heng LK., et al. "Validating the FAO Aqua Crop Model for Irrigated and Water Deficient Field Maize". Agronomy Journal 101 (2009): 488-498.

19. Hsiao TC. "Plant response to water stress". Annual Review of Plant Physiology 24 (2014): 519-570.

20. Munns R. "Physiological processes limiting plant growth in saline soil: some dogmas and hypotheses". Plant, Cell and Environment 16 (1973): 15-24.

21. Boyer JS. "Measuring the water status of plants and soils". Academic Press, San Diego (1995): 178.

22. Kawakami J., et al. "Effects of planting date on the growth and yield of two potato cultivars grown from microtubers and conventional seed tubers". Plant Production Science 8.1 (2005): 74-78.

Volume 3 Issue 8 August 2019

(C) All rights are reserved by Mguidich Belhaj A., et al. 